Editorial

\title{
Living Labs Past Achievements, Current Developments, and Future Trajectories
}

\author{
Dimitri Schuurman ${ }^{1, *}$ and Seppo Leminen ${ }^{2,3}$ (D) \\ 1 imec Ghent, Miriam Makebaplein 1, 9000 Ghent, Belgium \\ 2 Department of Business, Strategy and Political Sciences, University of South-Eastern Norway, \\ N-3007 Drammen, Norway; seppo.leminen@usn.no \\ 3 School of Business, Department of Marketing, Aalto University, P.O. Box 21230, FI-00076 Aalto, Finland \\ * Correspondence: Dimitri.Schuurman@imec.be
}

check for updates

Citation: Schuurman, D.; Leminen, S. Living Labs Past Achievements, Current Developments, and Future Trajectories. Sustainability 2021, 13, 10703. https://doi.org/10.3390/ su131910703

Received: 30 August 2021

Accepted: 5 September 2021

Published: 26 September 2021

Publisher's Note: MDPI stays neutral with regard to jurisdictional claims in published maps and institutional affiliations.

Copyright: (c) 2021 by the authors. Licensee MDPI, Basel, Switzerland. This article is an open access article distributed under the terms and conditions of the Creative Commons Attribution (CC BY) license (https:// creativecommons.org/licenses/by/ $4.0 /)$.
The year 2006 is the 'official' start of European Living Labs as the movement gained real momentum through European policy measures, culminating in the birth of the panEuropean network ENoLL (European Network of Living Labs) [1]. Living Labs (latter LLs) were closely linked to Testbeds and mainly focused on experimenting with novel technologies in a real-life context, especially in the context of ICT innovation [2]. However, over the years the outlook and thematic focus of LLs started to diversify and were influenced and fueled by the growth of European national and regional innovation networks, and pioneering companies [3]. LLs include multiple stakeholders and their roles [4-6]. Such network structures possess advantages for innovation in short and long terms [7-9]. Several studies have also looked into concrete impact and outcomes of LLs [10,11].

Nowadays, we consider LLs as platforms with shared resources, which organize their stakeholders into a collaboration network(s) that rely on representative governance, participation, open standards, and diverse activities and methods to gather, create, communicate, and deliver new knowledge, validated solutions, professional development, and social impact in real-life contexts [12]. LLs facilitate the development of people and communities for the use of innovation, i.e., they contribute to environmental and social improvements as well as economic development and mainly deal with so-called 'wicked problems' [11]. Moreover, LLs are regarded as innovation approaches linked to the generation and development of innovative business models [13] and innovation management approaches [14]. The LLs movement has grown to a worldwide phenomenon, both in terms of research and practice. ENoLL has already accredited nearly 500 LLs worldwide and currently counts more than 125 active members. In terms of publications, the search term "living labs" results in nearly 20,000 articles, of which more than $80 \%$ were written in 2015 or later, indicating that Living Labs has been gaining momentum.

This special issue on 'Innovation Management in LLs' is dedicated to the exploration and analysis of conceptual and theoretical foundations of LLs. This special issue is a collection of the ten best selected and reworked papers from the LL track at the ISPIM2020 conference, chaired by prof. Leminen and dr. Schuurman, and from the Open Living Lab Days 2020, with dr. Dimitri Schuurman as scientific chair of the conference. These events showed that both academic and practitioner interest in the concept of LLs is increasing.

\section{Living Labs in Mega, Meso, and Micro Levels}

As LLs are complex in nature, the literature has the tendency to mix up various aspects in relation to LLs. Schuurman [14] proposed a theoretical lens to distinguish three interlinked layers in LLs: the LL organization, the LL project(s), and the individual user and stakeholder activities. The top layer of the model can be associated with Open Innovation, whereas the bottom layer is in line with User Innovation. Both literature streams meet at the middle layer. Moreover, he made a distinction between LLs aiming at societal innovation 
and LLs focusing more on entrepreneurial innovation. The accepted papers are categorized in the special issue as follows (Figure 1):

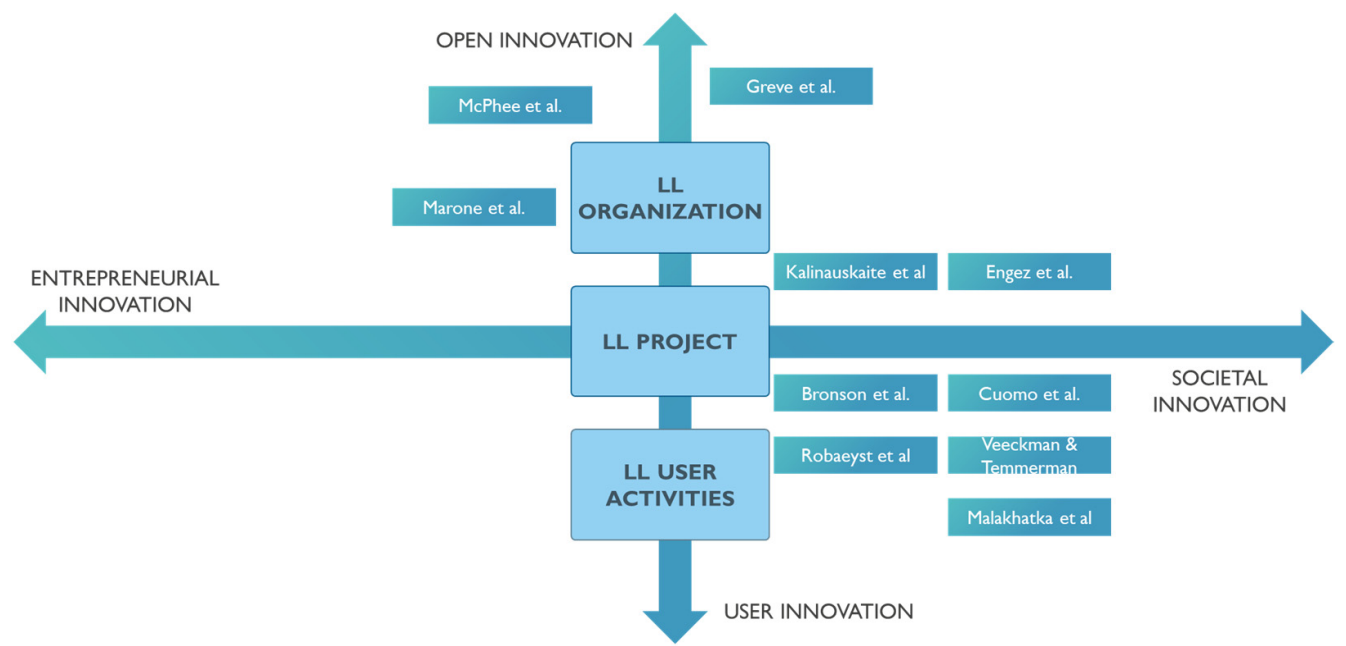

Figure 1. Mapping of the papers according to the type of innovation and the 3 levels of analysis within LLs.

The majority of the papers deal with societal innovation (8 out of 10), whereas the division between the three levels of LLs is more equal. Three papers focus on the organizational level, four papers are on the project levels, and remaining papers deal with the LL user innovation activities. Many LLs are focusing on societal innovation for solving 'wicked problems', whereas business and entrepreneurial innovation is practiced and researched less often $[13,15,16]$.

\section{Positioning Selected Articles}

Extant LL research offers many conceptualizations for LL, including but not limited to typologies [7], research avenues [16], bibliometric research [17,18], topic modelling [12], and systematic research [19-21]. Among them, [22] suggest that LL research includes three traditions or generations of LL research. According to authors, the first generation of LL research documents LL activities, where various users and stakeholders are engaged in real-life environments. The second generation of LL research focuses on explaining them from methodologies of innovative endeavors' points of view, where stakeholders are often intertwined in different phases of activities in LLs. The third generation focuses on understanding the core essence of LLs and their diverse conceptualizations, where LLs visualize such concepts. Table 1 attempts to grasp LL generations, theoretical foundations, contexts of study, and research approaches adopted in the selected articles.

Table 1. LL generation, theoretical foundation, context of study, and research approach.

\begin{tabular}{|c|c|c|c|c|c|}
\hline $\begin{array}{c}\text { Special Issue } \\
\text { Paper }\end{array}$ & $\begin{array}{l}\text { Living Lab } \\
\text { Generation }\end{array}$ & $\begin{array}{c}\text { Theoretical } \\
\text { Foundation (s) }\end{array}$ & Context of Study & $\begin{array}{l}\text { Research } \\
\text { Approach }\end{array}$ & Country \\
\hline Greve et al. [23] & Third generation & Living labs & $\begin{array}{l}\text { Innovation } \\
\text { management }\end{array}$ & $\begin{array}{c}\text { Bibliometric } \\
\text { research }\end{array}$ & Across countries \\
\hline Bronson et al. [24] & Third generation & Living labs & Agriculture & $\begin{array}{l}\text { Bibliometric } \\
\text { research }\end{array}$ & Across countries \\
\hline Engez et al. [25] & Third generation & $\begin{array}{c}\text { Urban living labs, } \\
\text { living labs, } \\
\text { ecosystems }\end{array}$ & Circular economy & $\begin{array}{l}\text { Multi-case } \\
\text { approach }\end{array}$ & Finland \\
\hline Cuomo et al. [26] & Third generation & Living labs & Circular economy & $\begin{array}{l}\text { Multi-case } \\
\text { approach }\end{array}$ & Italy, Netherlands \\
\hline
\end{tabular}


Table 1. Cont.

\begin{tabular}{|c|c|c|c|c|c|}
\hline $\begin{array}{l}\text { Special Issue } \\
\text { Paper }\end{array}$ & $\begin{array}{l}\text { Living Lab } \\
\text { Generation }\end{array}$ & $\begin{array}{c}\text { Theoretical } \\
\text { Foundation (s) }\end{array}$ & Context of Study & $\begin{array}{l}\text { Research } \\
\text { Approach }\end{array}$ & Country \\
\hline $\begin{array}{c}\text { Kalinauskaite et al. } \\
\text { [27] }\end{array}$ & Second generation & $\begin{array}{l}\text { Living labs, trans- } \\
\text { disciplinarycollab- } \\
\text { oration }\end{array}$ & Healthcare & $\begin{array}{l}\text { Multi-case } \\
\text { approach }\end{array}$ & Netherlands \\
\hline $\begin{array}{c}\text { Veeckman \& } \\
\text { Temmerman [28] }\end{array}$ & Second generation & $\begin{array}{l}\text { Urban living labs, } \\
\text { citizen science }\end{array}$ & $\begin{array}{l}\text { Environmental } \\
\text { policy }\end{array}$ & $\begin{array}{l}\text { Multi-case } \\
\text { approach }\end{array}$ & $\begin{array}{c}\text { Belgium, } \\
\text { Netherlands, } \\
\text { United Kingdom }\end{array}$ \\
\hline $\begin{array}{c}\text { Malakhatka et al. } \\
\text { [29] }\end{array}$ & Second generation & $\begin{array}{l}\text { Co-creation Living } \\
\text { labs }\end{array}$ & Built environment & Service design & Sweden \\
\hline McPhee et al. [30] & First generation & Living labs & Agriculture & $\begin{array}{l}\text { Multi-case } \\
\text { approach }\end{array}$ & Canada, France \\
\hline Marone et al. [31] & First generation & $\begin{array}{c}\text { Living labs } \\
\text { Urban Living Labs; }\end{array}$ & Healthcare & Single case study & Italy \\
\hline Robaeyst et al. [32] & First generation & $\begin{array}{l}\text { Social Open } \\
\text { Innovation }\end{array}$ & Social Innovation & Single case study & Belgium \\
\hline
\end{tabular}

The articles cover all the LL generations. For example, [30,31] document LLs in the context of agriculture and health care, and such articles represent a tradition of firstgeneration LLs, while [27-29], focus on co-creation, its process and phases in LLs in secondgeneration LLs. Greve et al. [23], Bronson et al. [24], Engez et al. [25], and Cuomo et al. [26] in turn offer various conceptualizations for LLs, which are part of discussion of thirdgeneration LLs. The co-guest editors emphasize that LL generations should not primarily be seen as an advancement indicator, but rather descriptions of larger research traditions that the researchers participate in and belong to. The articles of this special issue conclude diverse generations of LL research. The articles lean on literature of LLs and urban LLs, and multiple authors attempt to create bridges to citizen science, ecosystem, service design, and transdisciplinary collaboration literatures, among others.

The articles cover multiple contexts such as agriculture, built environment, circular economy, environment policy, healthcare, social innovation, and innovation management. This indicates that LLs are increasingly spreading and adopting challenges in such real-life contexts. The authors of this special issue primarily use a multi-case approach. Additionally, there are two studies that lean on a single case, and we also witness two bibliometric studies. The first focuses on innovation management and another one is in emerging field of agriculture LLs. The studied countries represent global perspectives but also European and Canadian perspectives for LLs including Belgium, Canada, Finland, France, Italy, Netherlands, Sweden, and United Kingdom. There are an increasing number of comparative multi case studies between different countries thus, describing the extensive utilization of such LLs worldwide as the Canadian-French perspective. Furthermore, the articles cover both northern and southern European perspectives of a single European country that focused on LL(s).

\section{Essence of Published Articles}

Ten articles were selected for this special issue based on evaluations of anonymous reviewers, the special issue editors, and Sustainability editors-in-chief. The articles were published between autumn 2020 and spring 2021 in Sustainability. The articles contribute multifold to understanding the field of LLs, as the articles reveal past achievements, current developments, and future trajectories of LLs.

The paper by Greve et al. [23] analyzes research of a LL landscape and creates conceptual bases mapping collaboration among scholars, themes, and the evolution of coauthorship network, and reveals extensive datasets of scholarly research by bibliometric research in innovation management. The results build bridges to other research domains by revealing their influence on scholarly research of LLs. Last, the authors position LLs as one of the major innovation streams. 
Bronson et al. [24] also adopt bibliometric research. They focus on agriculture and sustainable LLs. They contribute to the literature by revealing types of publications and an emergence of studied context. The results summarize the diversity on phases of innovation activities in a data set. The authors conclude the research approaches adopted in a study of agriculture and sustainable LLs in their data set.

Next, Engez et al. [25] focus on urban LLs in the context of circular economy and nutrient recycling in a multi-case setting including four cases. The authors contribute by analyzing diverse ecosystem structures in Finland, resulting in identifying three ecosystem types and their flows in an urban LL. Last, the article builds a bridge between LL and ecosystem research.

Cuomo et al. [26] discuss transformative urban LLs in a context of circular economy in Italy and Netherlands. Their study contributes to three dimensions: unconventionality, autonomy, and systemic impact on policies for analyzing LLs. The results of the study also contribute to determining controversial trajectories that depend on dimensions.

The paper written by Kalinauskaite et al. [27] focuses on transdisciplinary approaches in a context of healthcare using a multi-case approach including three cases in the Netherlands. Their analysis results in a conceptual framework to set up and initiate collaboration in LLs but also complex research and innovation ecosystems. The authors also map methods and deliverables in different collaboration phases.

Veeckman and Temmerman [28] adopt citizen science and urban LLs to analyze floods in urban cities, leaning on multi-case approaches in Belgium, Netherlands, and United Kingdom, including one case in each country. Their results suggest comparative results between the two chosen theoretical foundations. Particularly, such results show various impacts, such as social and spatial impacts, in the context of urban cities by coupling citizen science into urban LLs.

Malakhatka et al. [29] describe the methodologies of LLs. Thus, the authors analyze one built LL environment in Sweden through two lenses of co-creation. The study describes co-creation as innovation approach and a design practice in LLs. Their main contributions focus on classification of co-creation types in the single LL environment. Last, the study creates bridges to couple service and services design processes in urban LLs.

McPhee et al. [30] draw on agroecosystem LLs and analyze country-wide LL cases in Canada and France, including eight supporting cases. The study provides characteristics of agroecosystem LLs, meaning that such characteristics create a foundation in an emergent sub-field of agroecosystem LLs. The study brings closer seemingly different urban and rural LLs. Last, the study develops new types of LLs, namely agroecosystem LLs.

The study by Marone et al. [31] demonstrates a single LL that focuses on technological innovations in a context of healthcare in Italy. Their study develops understanding of stakeholder needs fostering innovation in LLs. Last, the results of the study identify particular activities that, coupled with stakeholder needs, suggest improving innovation process.

Finally, Robaeyst et al. [32] adopt a single case study design, looking into a Belgian social open innovation project on dyslexia and studying the nature of contextualized interactions between knowledge actors in the ecosystem and the processes of attraction, identification, selection, and activation of stakeholders in an urban LL (ULL). These insights converge in the development of a 'stakeholder acupuncture framework,' which structures mechanisms and practices within dynamic collaboration ecosystems and defines key boundary conditions for such open-ended ecosystems.

The LL special issue puts forward and further legitimizes the LLs as a field of major innovation management. The LL special issue proposes many substantial research opportunities for LL researchers. The articles enhance the theoretical and practical developments by offering many novel insights.

The special issue suggests various contributions and future avenues for LL research. For example, Greve et al. [23] suggest deepening analysis of the LL research and particularly factors that are associated with collaboration in LLs. Several studies cf. $[24,25,30]$ underline the need for either understanding the sustainability of LLs or the role of LL as a tool or a 
mechanism for better understanding sustainability both in urban and rural contexts. In this vein, McPhee et al. [30] call for future research to future conceptualize agroecosystem LLs and their unique characteristics. Studies also emphasize the need for further studies of co-creation processes, their phases, methods, and stakeholders associated processes and phases [27-29,31]. Engez et al. [24] also propose further research on understanding development of ecosystems and their roles in LLs. Hence, lenses of ecosystems for LLs deserve further attention in LLs [27]. Finally, the researchers suggest that LLs open novel research avenues that stimulate policy makers and public policy scholars cf. $[26,28]$ and that provide them with practical tools to foster multi-stakeholder participation and collaboration in an urban LL context cf. [32]. We hope that that the LL special issue inspires both researchers and practitioners in the fascinating and prominent research field of living labs.

Author Contributions: Conceptualization, S.L. and D.S.; methodology, D.S. and S.L.; formal analysis, D.S. and S.L.; writing — original draft preparation, D.S. and S.L.; writing—review and editing, D.S. and S.L.; supervision, D.S. and S.L.; project administration, D.S.; funding acquisition, D.S. and S.L. Special issue editorship: D.S. and S.L. Both authors have read and agreed to the published version of the manuscript.

Funding: This research received no external funding.

Institutional Review Board Statement: Not applicable.

Informed Consent Statement: Informed consent was obtained from all subjects involved in the study. Data Availability Statement: Not applicable.

Acknowledgments: Seppo Leminen warmly acknowledges the funding of a Drammen City Municipality for his Chaired Professorship of Innovation and Entrepreneurship, which enabled his part in the article.

Conflicts of Interest: The authors declare no conflict of interest.

\section{References}

1. Schuurman, D.; De Moor, K.; De Marez, L.; Evens, T. A Living Lab research approach for mobile TV. Telemat. Inform. 2011, 28, 271-282. [CrossRef]

2. Schuurman, D. Bridging the Gap between Open and User Innovation? Exploring the Value of Living Labs as a Means to Structure User Contribution and Manage Distributed Innovation; Ghent University: Ghent, Belgium, 2015.

3. Leminen, S.; Westerlund, M. Living labs: From scattered initiatives to a global movement. Creat. Innov. Manag. 2018, 28, 250-264. [CrossRef]

4. Nyström, A.-G.; Leminen, S.; Westerlund, M.; Kortelainen, M. Actor roles and role patterns influencing innovation in living labs. Ind. Mark. Manag. 2014, 43, 483-495. [CrossRef]

5. Leminen, S.; Westerlund, M.; Nyström, A.G. On becoming creative consumers-User roles in living labs networks. Int. J. Technol. Mark. 2014, 9, 33. [CrossRef]

6. Leminen, S.; Nyström, A.-G.; Westerlund, M. A typology of creative consumers in living labs. J. Eng. Technol. Manag. 2015, 37, 6-20. [CrossRef]

7. Leminen, S.; Westerlund, M.; Nyström, A. Living Labs as Open-Innovation Networks. Technol. Innov. Manag. Rev. 2012, 2, 6-11. [CrossRef]

8. Leminen, S.; Nyström, A.-G.; Westerlund, M.; Kortelainen, M.J. The effect of network structure on radical innovation in living labs. J. Bus. Ind. Mark. 2016, 31, 743-757. [CrossRef]

9. Leminen, S.; Nyström, A.-G.; Westerlund, M. Change processes in open innovation networks—Exploring living labs. Ind. Mark. Manag. 2020, 91, 701-718. [CrossRef]

10. Schuurman, D.; De Marez, L.; Ballon, P. The impact of living lab methodology on open innovation contributions and outcomes. Technol. Innov. Manag. Rev. 2016, 6, 7-16. [CrossRef]

11. Ballon, P.; Van Hoed, M.; Schuurman, D. The effectiveness of involving users in digital innovation: Measuring the impact of living labs. Telemat. Inform. 2018, 35, 1201-1214. [CrossRef]

12. Westerlund, M.; Leminen, S.; Rajahonka, M. A Topic Modelling Analysis of Living Labs Research. Technol. Innov. Manag. Rev. 2018, 8, 40-51. [CrossRef]

13. Rits, O.; Schuurman, D.; Ballon, P. Exploring the benefits of integrating business model research within living lab projects. Technol. Innov. Manag. Rev. 2015, 5, 19-27. [CrossRef]

14. Schuurman, D.; Herregodts, A.L.; Georges, A.; Rits, O. Innovation Management in Living Lab Projects: The Inno-vatrix Framework. Technol. Innov. Manag. Rev. 2019, 9, 63-73. [CrossRef] 
15. Westerlund, M.; Leminen, S.; Habib, C. Key Constructs and a Definition of Living Labs as Innovation Platforms. Technol. Innov. Manag. Rev. 2018, 8, 51-62. [CrossRef]

16. Leminen, S.; Westerlund, M. A framework for understanding the different research avenues of living labs. Int. J. Technol. Mark. 2016, 11, 399-420. [CrossRef]

17. Greve, K.; Leminen, S.; De Vita, R.; Westerlund, M. Unveiling the diversity of scholarly debate on living labs: A bibliometric approach. Int. J. Innov. Manag. 2020, 24. [CrossRef]

18. McLoughlin, S.; Maccani, G.; Prendergast, D.; Donnellan, B. Living Labs: A Bibliometric Analysis. In Proceedings of the 51st Hawaii International Conference on System Sciences, Kauai, HI, USA, 2-8 January 2018; pp. 4463-4472.

19. Ballon, P.; Schuurman, D. Living labs: Concepts, tools and cases. Info 2015, 17, 1-11. [CrossRef]

20. Dekker, R.; Contreras, J.F.; Meijer, A. The Living Lab as a Methodology for Public Administration Research: A Systematic Literature Review of its Applications in the Social Sciences. Int. J. Public Adm. 2020, 43, 1207-1217. [CrossRef]

21. Hossain, M.; Leminen, S.; Westerlund, M. A systematic review of living lab literature. J. Clean. Prod. 2019, 213, 976-988. [CrossRef]

22. Leminen, S.; Rajahonka, M.; Westerlund, M. Towards Third-Generation Living Lab Networks in Cities. Technol. Innov. Manag. Rev. 2017, 7, 21-35. [CrossRef]

23. Greve, K.; Vita, R.; Leminen, S.; Westerlund, M. Living Labs: From Niche to Mainstream Innovation Management. Sustainability 2021, 13, 791. [CrossRef]

24. Bronson, K.; Devkota, R.; Nguyen, V. Moving toward Generalizability? A Scoping Review on Measuring the Impact of Living Labs. Sustainability 2021, 13, 502. [CrossRef]

25. Engez, A.; Leminen, S.; Aarikka-Stenroos, L. Urban Living Lab as a Circular Economy Ecosystem: Advancing Environmental Sustainability through Economic Value, Material, and Knowledge Flows. Sustainability 2021, 13, 2811. [CrossRef]

26. Cuomo, F.; Ravazzi, S.; Savini, F.; Bertolini, L. Transformative Urban Living Labs: Towards a Circular Economy in Amsterdam and Turin. Sustainability 2020, 12, 7651. [CrossRef]

27. Kalinauskaite, I.; Brankaert, R.; Lu, Y.; Bekker, T.; Brombacher, A.; Vos, S. Facing Societal Challenges in Living Labs: Towards a Conceptual Framework to Facilitate Transdisciplinary Collaborations. Sustainability 2021, 13, 614. [CrossRef]

28. Veeckman, C.; Temmerman, L. Urban Living Labs and Citizen Science: From Innovation and Science towards Policy Impacts. Sustainability 2021, 13, 526. [CrossRef]

29. Malakhatka, E.; Sopjani, L.; Lundqvist, P. Co-Creating Service Concepts for the Built Environment Based on the End-User's Daily Activities Analysis: KTH Live-in-Lab Explorative Case Study. Sustainability 2021, 13, 1942. [CrossRef]

30. McPhee, C.; Bancerz, M.; Mambrini-Doudet, M.; Chrétien, F.; Huyghe, C.; Gracia-Garza, J. The Defining Characteristics of Agroecosystem Living Labs. Sustainability 2021, 13, 1718. [CrossRef]

31. Marone, L.; Onofrio, R.; Masella, C. The Italian Case of Lecco Innovation Living Lab: Stakeholders' Needs and Activities to Contribute to the Technological Innovation Process in Healthcare. Sustainability 2020, 12, 10266. [CrossRef]

32. Robaeyst, B.; Baccarne, B.; Duthoo, W.; Schuurman, D. The City as an Experimental Environment: The Identification, Selection, and Activation of Distributed Knowledge in Regional Open Innovation Ecosystems. Sustainability 2021, 13, 6954. [CrossRef] 